\title{
Improving processes and natural production minerals recycling
}

\author{
Natalia Khrunina $^{1 *}$ and Anton Cheban ${ }^{1}$ \\ ${ }^{1}$ Mining Institute of Far eastern branch of Russian Academy of Sciences, Khabarovsk, Russia
}

\begin{abstract}
Annotation. The article is devoted to improving the processes of extraction of natural carbon minerals through increased selectivity and reduce dilution, as well as processing of ash-slag wastes to reduce environmental burdens and increasing complexity of extracting minerals. Data are elemental and mineral composition, energy dispersive microanalysis by scanning electron microscope JEOL JCM-6000. As a result of natural objects analysis carbon minerals, with their typing on structural and mineralogical composition, marked by the characteristic difficult structural signs plastoobraznyh and lenticular deposits. A method of treatment of structured development of carbonaceous deposits of minerals based on the improved design of the working body of the harvester, that will increase the efficiency of minerals through mining selectivity. As a result, microanalysis samples ash wastes found the presence of native gold, platinum and silver. The application of ways of dressing of secondary raw materials using innovative technologies developed, based on the processes of gravitational and ultrasonic cavitation effects, provide comprehensiveness of allocating valuable components micron level and reduce the pollution of Wednesday.
\end{abstract}

\section{The urgency of the problem}

At present the most important problems of mineral development remain mineral loss, ensuring selectivity indentations, complexity of recovery of valuable components and reduce the adverse impact on the Wednesday $[1,2]$. Gets the development direction research of processes of extraction of valuable components from waste carbon minerals of different genesis, it should be noted, however, that the bulk of the commodity mined open pit [3]. Prevalence is wide enough abundance of coal in the form of reservoirs, plastoobraznyh and lenticular deposits. The data also contain deposits of clay, sand, argillites, siltstones, sandstones. The content of toxic and reactive compounds pollution danger Wednesday [4]. One of the characteristic of spatial objects take major complexes in the far eastern region is the Luchegorskij Colliery, that includes sand-gravel and sandy-argillaceous rocks, fig. 1 [5-6].

To produce deeply selective dredging minerals from the treatment of structured arrays allow mountain combines. Application of combine harvesters allows to refuse from drilling and blasting, enhances the extraction ratio and to improve the quality of the extracted mineral resources [7-16]. Escalating of volumes of coal, provided for the energy strategy of Russia's development, and decrease its cost is impossible without technical re-equipment of

\footnotetext{
*Corresponding author: npetx@mail.ru
} 
mining enterprises. As already mentioned, a number of coal and oil shale deposits are characterized by the complex structure, where the mineral layers interspersed with empty rocks, the power of layers and interlayers can range from a few metres to a few centimeters.

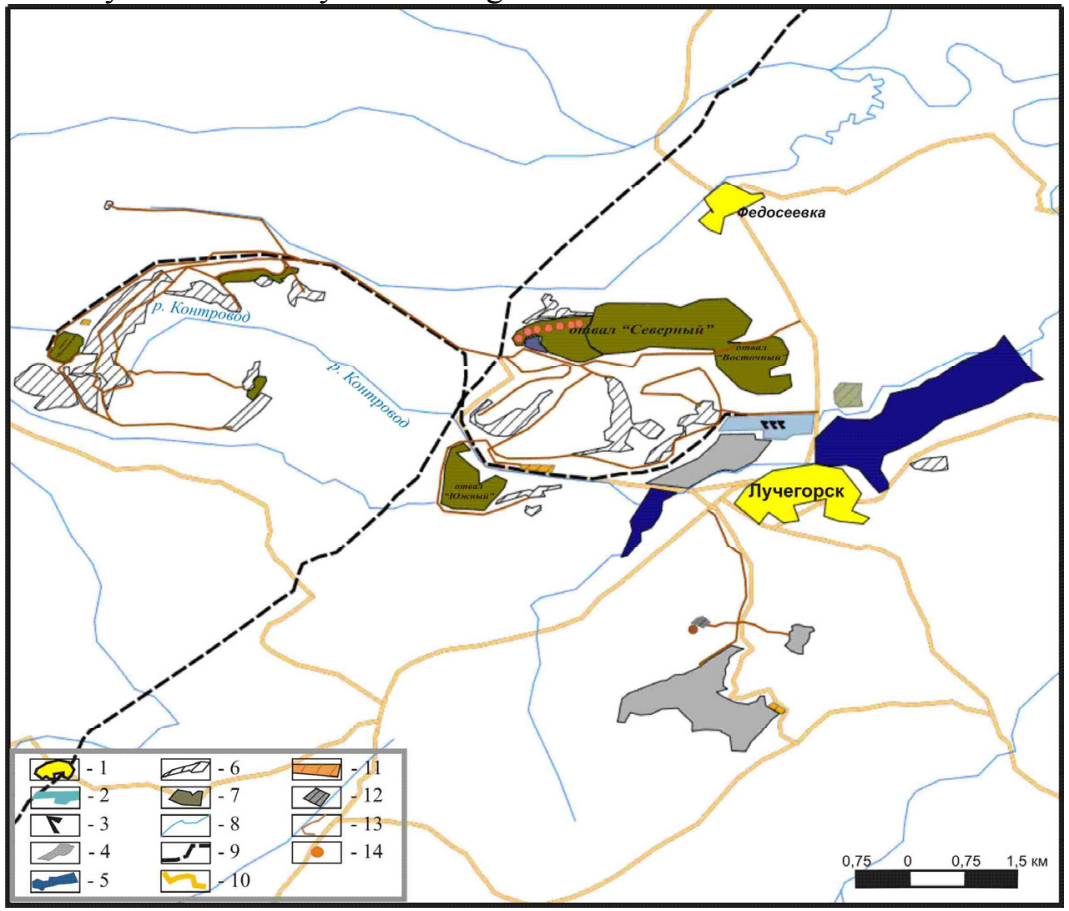

Fig. 1. Luchegorskij coal incision [5]: 1 - human settlements; 2 - technological complex of Seaside GRES; 3 - boilers, boiler emissions into the atmosphere; 4 - ash dumps; 5 - pond-cooler of Seaside GRES; 6 - coal cuts; 7 - dumps of rocks; 8 - river network; 9 - railways; 10 - road; 11 - auxiliary production; 12 - SLR «Jekomett»; 13 - coal road; 14 - the point of testing dumps

The development of such deposits using traditional technologies, in which loosening of the array is done by blasting method, and excavation of rock work is conducted by, not allows highly selective dredging, leads to mixing of mineral with an empty rock. And this in turn will affect the subsequent comprehensive recovery of precious components from waste coal (schist).

The aim of the study is a comprehensive solution to the problem, includes improving processes the natural production of carbon minerals through increased selectivity dredging and reduce the dilution, as well as the processing of ash-slag wastes to reduce environmental burdens and increasing complexity of extracting minerals.

\section{Research methods}

In the laboratory of mineral processing IGD FEB RAS studied material composition ash wastes Seaside GRES [17] and experimental study on intensification of extraction processes of gravity of noble metals. Using scanning electron microscope JEOL JCM-6000 PLUS NEOSCOPE (JEOL, Japan) carried out by energy dispersive microanalysis samples. Accelerating voltage $15 \mathrm{kV}$, probe talk $7.475 \mathrm{nA}$. Systematic error of scanning electron microscope JEOL JCM-6000 PLUS NEOSCOPE When all requirements is within 0.01-0.001 [18-19]. When analyzing the current status of machinery and mineral extraction and processing technologies used phenomenological approach to creating effective technologies and means for their implementation. 


\section{Experimental results and discussion}

Electron-microscopic examination of the original Ash on raster electronic microscope JEOL (Japan), with energy dispersing Analyzer "JCM-6000 PLUS" revealed the presence not only of gold, but Platinum and silver, fig. 2.

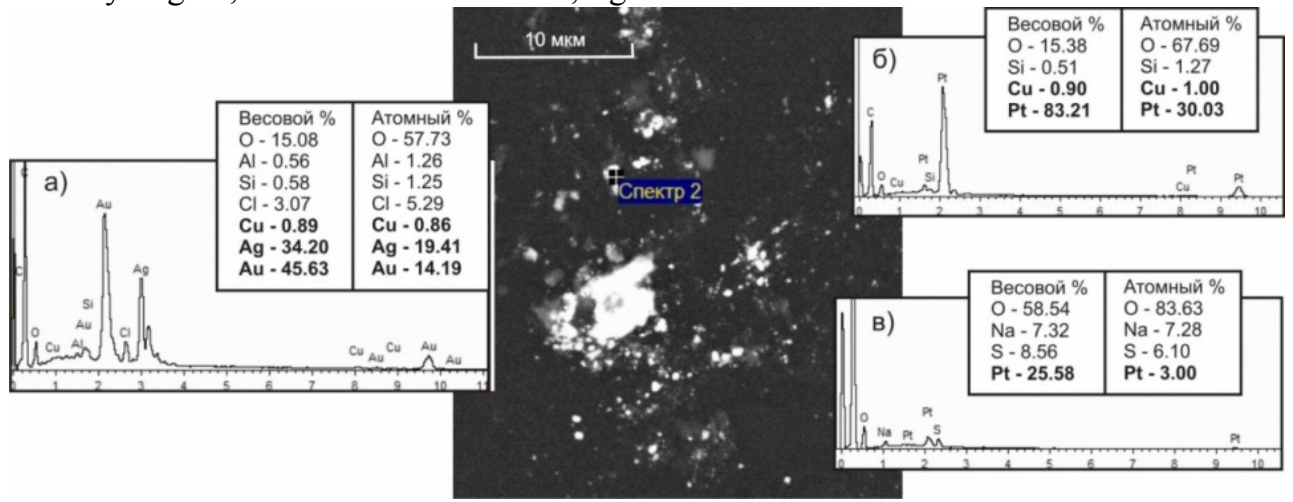

Fig. 2. Disperse accumulation of grains and precious metals $(0.5-10 \mu \mathrm{m})$ in the original ash (class size + 2.0): a) kjustelit $\mathrm{Ag}_{3} \mathrm{Au}_{2}(1 \mu \mathrm{m})$; b) samorodnaja Platinum (Pt) mixed with copper $(0.5 \mu \mathrm{m})$; c) kuperit PtS $(1 \mu \mathrm{m})$ in srastanii with tenarditom $\mathrm{Na}_{2} \mathrm{SO}_{4}$.

As a result of physical and chemical processing of ash formations before the gravitational enrichment process material reduced loss of fine gold.

Improvement of extracting carbon minerals affect the use of products of its enrichment and reprocessing of wastes are valuable components in a comprehensive range of source. With a view to intensify the destruction treatment of structured arrays of stacked rocks vary in strength properties, developed the executive bodies of the mountain combines with a combined cutting tools. To create executive bodies is to expand the technological capacity of mining equipment, reducing energy intensity and increasing the productivity of cutting process when working in periodically changing mining and geological conditions. The virtues of the techniques of dredging coal and shale oil an important drawback is the presence of a large number of small factions in the mined minerals, which reduces their quality and market value, as well as prejudice loss mountain mass loading, transportation, handling and storage.

Burning of coal containing significant amounts of fines, leads to a decrease in the efficiency of combustion devices, reduces efficiency and environmental safety of fuel used. To improve the quality of coal and oil shale producing their sorting with removing trivia, resulting in accumulating a huge amount of waste [20-24]. According to the domestic classification of coal size pieces divided into groups and classes, there are two groups of coals: varietal and combined. High-quality coal are in high demand and have a greater market value.

To comprehensively address the problem of extracting carbon raw materials and processing of secondary raw materials in the IGD FEB RAS method treatment of structured development of coal deposits using the career combine as well as gravity concentration technology secondary carbon minerals extraction-based small and fine particles of valuable components more environmentally and technologically effective means [25-26]. The authors developed and offered systems modelling processes of multistage Jet-acoustic disintegration mineral components of hydraulic fluid by using hydrodynamic kavitatorov [26] and ultrasonic processing complex [25]. Integrated coalfield development scheme (shale) and recycling (slags, slimes) are presented in figure 3. 


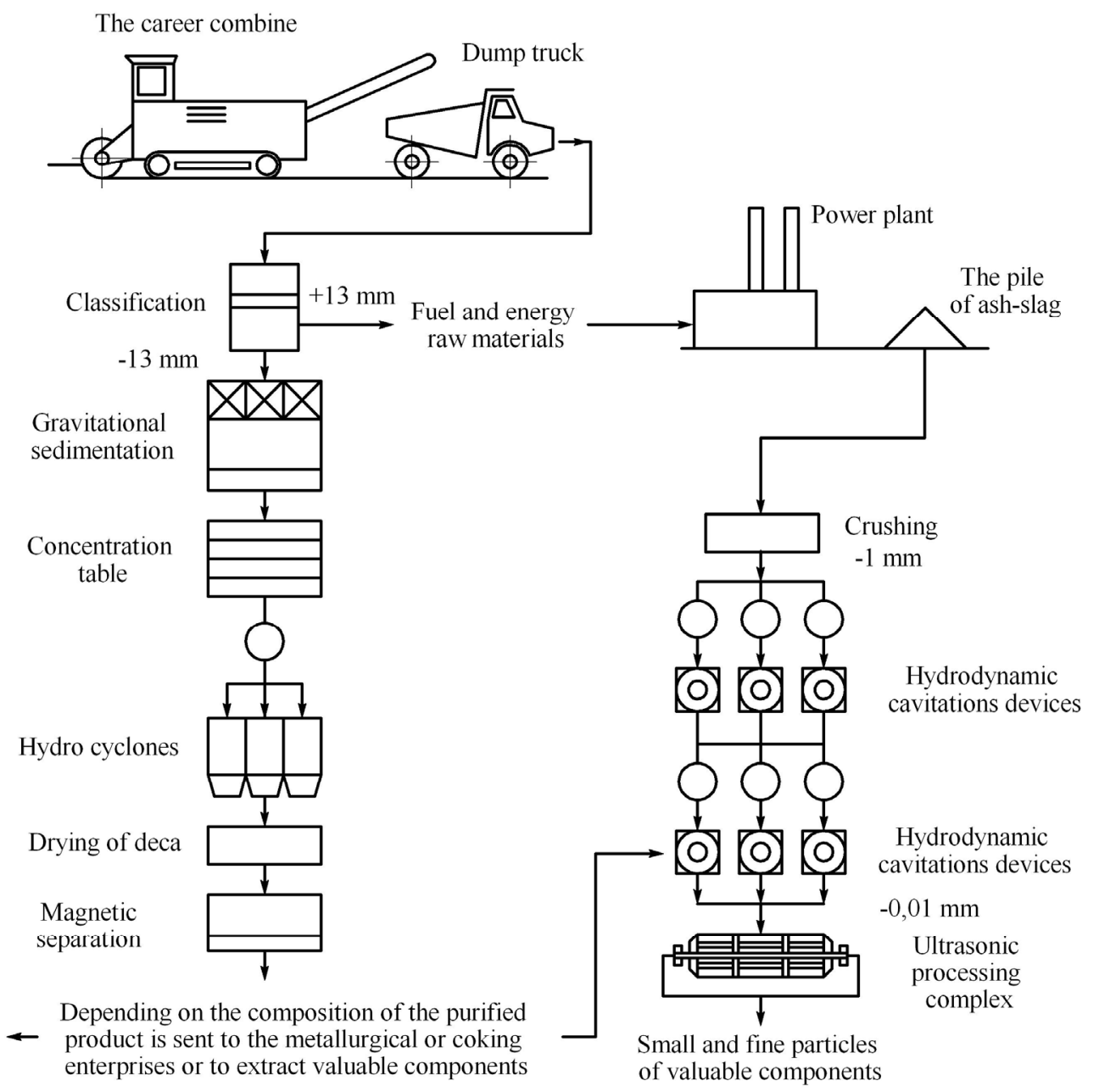

Fig. 3. Scheme of integrated development of coal deposits and processing of secondary raw materials

Method of treatment of structured development of coal deposits using the career combine and the Special Executive Body with variable placement scheme and long incisors includes the required stress concentrations by regulating cutting forcesin the area of processing and shaping in the surface layer of processed array destruction zones using cutting tools working body combine depending on strength characteristics of rock across the width of the workpiece when you change functional parameters-rotation speed shell working body and forward speed combine in their rational combination. Automatic control system of process includes fixation strength characteristics of the breed registration sensor strength. Selective development of ensuring reduction of coal grinding is performed by increasing the step placement coal cutting tools in relation to step placement rock cutting tools, when this fixation discs with cutting tools in working position is carried out automatically stops. The proposed body and how its application would increase selectivity when designing mountain combines treatment of structured deposits, reduce coal pereizmelchenie (Slate) and razubozhennost minerals.

To address the issue of mikrodezintegracii, with the purpose of extraction of fine particles of valuable components more technologically effective means can be used by system processes based on the cavitation acoustic impact on mineral content of hydraulic fluid [25- 
28]. For the processing of ash-slag wastes, including fine component to retrieve the Micron particles of valuable components in IGD FEB RAS designed complex with an ultrasonic initiation based on the principle of cavitation effects on mineral gidrosmes in tonkoslojnom thread [25] and affusion hydrodynamic cavitations device [26].

Cavitation reactor systems provide tonkostrujnoe particle with increased acoustic cavitation effects on fine mineral content of hydraulic fluid. Ultrasonic processing complex [25] contains a multilevel partition Dec with riffles, loosening system and regulate the flow of pulp and flushing water. Surface emitting ultrasound transducers are aimed towards trap surfaces Dec taking into account the direction of flow of pulp. Intensifies the intensification of disaggregation and the destruction of relationships between particles of gangue and precious minerals. Processing complex is designed for high performance due to increased surface Dec installed a few levels. This will improve performance and removing particles of valuable minerals from the secondary minerals are smaller than $0.1 \mu \mathrm{m}$.

\section{Conclusion}

As a result of natural objects analysis carbon minerals, with their typing on structural and mineralogical composition, marked by characteristic signs of slozhnostrukturnye deposits. As a result, microanalysis samples ash wastes seaside gres found the presence of native gold, platinum and silver.

For a comprehensive solution to the problem of slozhnostrukturnogo and natural plastoobraznogo extraction and processing of secondary raw material carbon tehnological possibility and feasibility of introducing mountain combines improved designand the use of new gravitational ways of dressing of the secondary carbon minerals based on hydrodynamic cavitation and impact of ultrasound exposure at the micro level to retrieve valuable microparticles components.

Work is performed within the framework of the project № 15-1-2-060 Program FNI "Far East".

\section{References}

1. T. Moskalenko, E. V. Nap, Irkutsk State. Tech. Irkutsk, 10, 98-102. (2014).

2. M. Y. Nazarenko, N. K. Kondrasheva, S. N. Saltykova, V.Y. Bazhin, News of Tomsk Polytechnic University. UN-Ty. Engineering for georesources (udsc), 327 (3) 67-74. (2016).

3. Y. M. Linnik, Yuri Linnik, Mining equipment and electromechanics, 10, 2-6. (2012).

4. N. P. Khrunina, A. Yu. Cheban, Vestnik Magnitogorskogo Gosudarstvennogo Tekhnicheskogo Universiteta im. G.I. Nosova, 4, 50-55. (2015).

5. M. B. Bubnova, Problems of integrated development for georesources (udsc): proceedings of the VI Vserocsijskoj scientific conference with participation of foreign scientists (Khabarovsk, Russia, 05-07 October, 2016 г.)-Khabarovsk: IGD Feb RAS, 183-189 (2017)

6. I. Kalinin, Evaluation of structural-tectonic structure of landslide slopes coal incisions using electrical tomography: example Luchegorskogo lignite cut: thesis. candidate of technical sciences: 25.00.16, Vladivostok (2006).

7. A. Yu. Cheban, , G. V. Sekisov, N. P. Khrunina, S. A. Shemyakin, Eurasian mining, 1, 22-24 (2014).

8. A. Grabski, Mining, 4, 60-62. (2010).

9. A. Y. Cheban, N. P. Khrunina, S. A. Shemyakin, Proceedings of the Ural State. Mining University, 4(44). 54-56. (2016). 
10. Mohd Imran, International Journal of Technical Research and Applications, 01, 224226. (2016).

11. S.K. Palei, N.C. Karmakar, P. Paliwal, B. Schimm, International Journal of Research in Engineering and Technology, 02, 393-396. (2013).

12. K. Dey, A. K. Ghose, Journal of Mines, Metals and Fuels, 56(5). 85-92. (2008).

13. A. Y. Cheban, Magnitogorsk State. Tech. UN-Ty them. G.i. Nosova, 14(2). 5-9. (2016).

14. A. K. Ghose, Journal of Mines Metals and Fuels, 56(3, 4) 41-43. (2008).

15. K. Dey, K. Pathak, P. Sen, National Seminar on Mining in the New Millennium, 10-12 November 2000. - Hyderabad, 136-142. (2000).

16. M. Pichler, Y.B. Pankiewicz, in Nikolaev, mining, 3, 20-22. (2006).

17. A.V. Rasskazova, N. A. Lavrik, N. M. Litvinova, R. V. Bogomjakov, Mountain information-analytical bulletin, S21, 282-296. (2016).

18. N. M. Litvinova, N.A. Lavryk, V. B. Bubnova, V. G. Kryukov, R.V. Bogomjakov, K.V. Prokhorov, The journal «Ecological chemistry», 27 (2), 99-109. (2017).

19. R. V. Bogomjakov. N. M. Litvinov, A. V. Rasskazova, N. P. Chrunina, Inventions, utility models as a waitress. Newsletter, 7 (2018).

20. A. Y. Cheban, N. P. Khrunina, Science and education, 2(82) 26-31 (2016).

21. I. Demchenko, A mountain of information and analitecheskij bulletin, 5, 120-122. (1997).

22. Yuri Shuvalov, J. D. Tarasov, A. N. Nikulin, A mountain of information and analitecheskij bulletin, 8, 243-247. (2011).

23. R. Leimbi-Merike, H. Tiina, L. Eneli, K. Rein, Oil shale, 31(2). 147-160. (2014).

24. Q. Wang, J. Bai, J. Ge, Y.Z. Wie, S. Li, Oil shale, 31(3). 266-277. (2014).

25. N. P. Khrunina, Inventions, utility models as a waitress. Newsletter, 18. (2004).

26. N. P. Khrunina, Inventions, utility models as a waitress. Newsletter, 4. (2014).

27. V. V .Elshin, S. A. Melnyk, Austrian Journal of Technical and Natural Sciences, 9-10. 114-118. (2014).

28. Zhi-Jun Dai, Zhen-Bang Kuang, She-Xu Zhao, Transport in Porous Media, 65, 237264. (2006). 